\author{
Beata Telatyńska \\ Dolnośląska Szkoła Wyższa we Wrocławiu \\ telatynska@wp.pl
}

\title{
Możliwości współczesnej recepcji utworów Stanisława Jachowicza, dydaktycznej literatury dziewiętnastowiecznej ${ }^{1}$
}

\begin{abstract}
Summary
Opportunities for contemporary reception of works by Stanisław Jachowicz, the didactic literature on the nineteenth century

Prior to the nineteenth century, literature aimed particularly at children did not exist. Only romanticism saw the great potential that the engagement with the topic of childhood offered. In Poland Stanislaw Jachowicz - Polish storyteller, educator and charity activist-achieved s significant successes in this field. In this article, the author presents Jachowicz's work from two perspectives. By conducting a nineteenth century and a contemporary reading of his narrations, she examines the possible contexts of reading Jachowicz's didactic literature, concentrating primarily on his fairy tales. Although, from the point of view of contemporary pedagogy, Jachowicz's educational methods are outdated and inadequate to give guidance on the realities that the children of today face, one can find universal elements in the writer's work, for example, respect for another person, work, money or empathy. The modern reader is invited to gain a better understanding of the realities of the nineteenth century family and confront these insights with the challenges and the hopes of the present day.
\end{abstract}

Słowa kluczowe: bajkopisarstwo romantyczne, literatura dla dzieci, literatura dydaktyczna, pedagogika XIX wieku, Stanisław Jachowicz

Keywords: children's literature, educational literature, nineteenth century pedagogy, romantic fable, Stanisław Jachowicz

\footnotetext{
1 Artykuł jest częścią projektu finansowanego w ramach innowacyjnego programu badawczo-szkoleniowego Unii Europejskiej Horyzont 2020, działanie Maria Skłodowska-Curie, numer umowy grantowej 676452. The paper is part of a project that has received funding from the European Union's Horizon 2020 research and innovation programme under the Marie-Sklodowska-Curie grant agreement number 676452 .
}

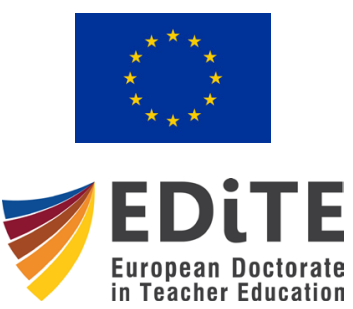




\section{Wprowadzenie}

Koncepcja bajki dla dzieci i młodzieży nie zrodziła się, wbrew obiegowym przekonaniom, w Oświeceniu, ani w czasach La Fontaine’a, mimo że cieszyła się wówczas dużym powodzeniem. Zanim powstało oryginalne piśmiennictwo dla dzieci, wychowawcy posługiwali się tekstami literatury wysokiej, klasyki, podającymi gotowe wzorce etyczne i edukacyjne. Potrzeby czytelnicze dzieci zaspokajane były przekazem ustnym w postaci baśni, legend, mitów. Do rąk dziecięcych trafiały bajki Ezopa, eposy Homera. Dopiero przełom romantyczny przyniósł nowe spojrzenie na dziecko. Dzieciństwo urosło do rangi hasła programowego, dziecko stało się figurą poetycką, symbolem, za pomocą którego wyrażano pokoleniowe rozterki i pragnienia. Romantycy zachowali oświeceniowy szacunek dla dziecka jako tworu delikatnego i wymagającego opieki, nie przygotowywali go jednak do pełnienia zadań społecznych, wręcz odwrotnie, pragnęli uchronić naturalność i niewinność dzieciństwa przed dorosłością. W pierwszej połowie XIX wieku pedagodzy w całej Europie posługiwali się gotowymi tekstami z literatury wysokiej bądź preparowanymi w taki sposób, by przekazywały właściwe wzorce edukacyjne i moralne. Na potrzeby wychowania dzieci tworzono adaptacje znanych utworów klasyki światowej: Przypadków Robinsona Cruzoe Daniela Defoe, Don Kichote'a Cervantesa, Podróży Guliwera Jonathana Swifta i wielu innych. Młody odbiorca funkcjonował na skrzyżowaniu dwóch obiegów literatury: tekstów pisanych specjalnie dla niego, w większości przez pedagogów oraz utworów adaptowanych z literatury ogólnej.

W niniejszym artykule skupiam uwagę na pedagogicznych aspektach twórczości Stanisława Jachowicza. W pierwszej części przedstawiam pokrótce twórczość dla dzieci w XIX wieku. Na tym tle przybliżam postać S. Jachowicza jako bajkopisarza, pedagoga, działacza społecznego, a w końcowej części piszę o współczesnej recepcji i potencjale wychowawczym jego twórczości.

\section{Działalność i twórczość Stanisława Jachowicza}

Aktywność pedagogiczną Stanisława Jachowicza (1796-1857) - bajkopisarza, pedagoga, działacza charytatywnego, „kapłana biednych” (Skimborowicz 1858: 58) można porównać z działaniami Jana Henryka Pestalozziego, szwajcarskiego pedagoga oraz Friedricha Froebla, żyjącymi na przełomie XVIII i XIX wieku, reformatorami edukacji, zainteresowanymi przede wszystkim pomocą dzieciom wywodzącym się z ludu. Pestalozzi kształcenie intelektualne ucznia powiązał z praktyczną nauką zawodu i doceniał wartość rodziny w procesie edukacji dziecka. Froebel w swojej pracy wychowawczej główny nacisk kładł na rozwój fizyczny, moralny i umysłowy małych dzieci (Wołoszyn 1964). Wykreowana przez nich postać nauczyciela przedstawiała osobę zaangażowaną nie tylko w edukację, ale i pozaszkolne wychowanie ucznia.

Jachowicz w pracy i prywatnie wraz z drugą żoną realizował życiowe postulaty. Zanim doczekali się dwóch własnych synów, adoptowali osieroconą uczennicę oraz czwór- 
kę dzieci zmarłej siostry żony. Jego dom zawsze był swego rodzaju ośrodkiem działań wydawniczych, pedagogicznych i społecznych. Rodzice skrzętnie notowali obserwacje na temat rozwoju dziecka, szczególnie w zakresie rozwoju mowy na przykładzie swoich synów: Eryka i Rudolfa (Jachowicz, Jachowicz 1846-1851). W szkole ceniono Jachowicza za urozmaicone wykłady oraz odwoływanie się do doświadczeń odbiorców (Szymanowski 1858).

Utwory Jachowicza trudno nazwać literaturą piękną. Brak w nich dbałości o formę i artystyczny kształt. Mimo że powstały w latach 20. XIX wieku, mocno osadzone są w utylitarnej i praktycznej ideologii poprzedniego stulecia. Jednak współcześni poecie doceniali jego utwory za prostotę języka, odpowiednią dla mniej wykształconej warstwy społeczeństwa, jakże odmienną formę od tej, do której przyzwyczaiła odbiorców oświeceniowa twórczość. Jachowicz zdecydowanie największy nacisk położył na walory edukacyjne swojej twórczości, nie zabiegając o kształt artystyczny. Nie uprawiał różnych form literackich. Wzorując się na utworach Ignacego Krasickiego, stworzył teksty, które charakteryzuje zwięzła treść, lapidarność, epigramatyczna przejrzystość. Oryginalne niewątpliwie jest dostosowanie utworów do psychiki odbiorcy oraz serdeczny i pobłażliwy ton. Teksty Jachowicza odwołują się do surowych ideałów wychowawczych, utrzymanych jeszcze w stylu oświeceniowym. Uczą przede wszystkim pracowitości, posłuszeństwa, uczciwości, sumienności, cierpliwości, poszanowania starszych, dobroci dla ludzi i zwierząt. Dydaktyka w jego wykonaniu musiała nieraz przestraszyć, ale zawierała również elementy humorystyczne. Najważniejszą innowacją w konstrukcji jachowiczowskiego gatunku była jednak rezygnacja $\mathrm{z}$ alegorii - nie zawsze zrozumiałej dla dziecięcego odbiorcy. Ważnym elementem, szczególnie w późniejszym okresie, jest uwypuklenie znaczenia pracy i szacunku do niej, godności osobistej na tle aktualnych problemów w skali miasta i kraju.

Niemożliwe jest rozpatrywanie twórczości pisarza bez uwzględnienia kontekstu sytuacji politycznej kraju po upadku powstania listopadowego, ówczesnej walki o ojczysty język i demokrację i poprawę stosunków społecznych. Jak pisze Izabella Kaniowska Lewańska:

Zrozumiałe będzie wówczas żarliwe dążenie do kształtowania charakteru ze stawianiem na pierwszym miejscu prawości, solidarności społecznej, pracowitości, chęć dostarczenia też materiałów kształcących dla wychowawców, matek - zastąpienie kasowanych szkół (Kaniowska-Lewańska 1973: 80).

\section{Współczesne spojrzenie na spuściznę Jachowicza}

Twórczość Jachowicza żyła nie tylko do końca XIX wieku, ale także w późniejszym okresie. Okrzyknięto go ojcem polskiej literatury dla najmłodszych. Do dziś najbardziej rozpoznawanym utworem poety jest słynny Chory kotek. Jednak nadmierne moralizatorstwo, nierealistyczny obraz biblijnego porządku świata, w którym posłusznych spotyka dobro, 
a niegrzecznych kara zostało wytknięte Jachowiczowi już na początku XX wieku za sprawą sparodiowanych bajek w Stówkach Tadeusza Boya-Żeleńskiego².

Model nauczyciela propagowany przez Jachowicza przyjmuje w procesie edukacyjnym rolę autorytetu, który „wie lepiej” z racji swojego wieku, pozycji społecznej i autopsji. Widać to szczególnie w bajkach i powiastkach (Jachowicz 1860: 73, Jachowicz 1824: 13-14) oraz w utworze Rady wuja dla siostrzenic. Tytułowy doświadczony krewny, mając na celu dobro swoich wychowanek, podkreśla istotę tradycyjnego modelu małżeństwa:

Żona męża trud osłodzi i raj ziemski mu założy (...) Mąż panuje władzą, siłą, a kobieta ma być miłą, słodką, cichą, nieuporną, pobłażliwą i pokorną (Jachowicz 1855b: 12-13).

Jachowicz zabiegając o wykształcenie oczekiwanych postaw moralnych, kieruje się wiedzą potoczną, obciążoną stereotypizacją, wyrastającą z własnych doświadczeń. Model edukacji propagowany przez Jachowicza przypomina „bankowy” (Freire 2000, 1992), w którym uczeń przyjmuje depozyt otrzymany od nauczyciela. Pedagog jest osobą, która przekazuje wiedzę, nie dopuszczając do jej samodzielnego poszukiwania, zdobywania i doświadczania. Nie ma także możliwości uczenia się nauczyciela od ucznia, ponieważ uczeń jest bierny w procesie uczenia. Takie podejście dalekie jest od konstruktywizmu, w którym wiedza jest subiektywna a dziecko konstruuje własne rozumienie świata poprzez doświadczanie i selekcję zdobytej wiedzy. Rolę wychowawcy u Jachowicza pełni nie tylko odautorskie ,ja”, lecz przede wszystkim poszczególni członkowie rodziny: matka (Staś3), ojciec (Lorcia), dziadek (Wieczór pod drzewkami), rzadziej inne dziecko (Dworek pod laskiem). Zdarza się, że pouczeń udziela rodzic ze świata zwierząt, np. mysz (Myszka na śniadaniu), mrówka (Mrówka). W tak skonstruowanej relacji można spodziewać się zaistnienia zjawiska pułapki izonomii (Czerepaniak-Walczak 1994), gdy uczeń zdejmuje z siebie odpowiedzialność za własne kształcenie, oczekując, że ktoś kompetentny wskaże mu drogę postępowania. Ponadto uwidacznia się siła mitu autorytetu (Vališová 2015). Jachowicz wyraźnie podkreśla, że tylko dorosły może wykształcić w dziecku pożądane cechy i wymaga akceptacji tego faktu ze strony dziecka, podając za przykład drzewko, które daje się ugiąć, kiedy jest młode (Adaś) lub psa Kruczka, który szybciej nauczył się sztuczek, kiedy był jeszcze szczeniakiem. Uczeń musi ten układ zaakceptować, nawet jeśli, tak jak np. Kruczek, nie ma na to ochoty i zgodnie z naturą woli zabawę (Piesek Kruczek).

Behawioralna edukacja u Jachowicza opiera się na systemie nagród i kar. Dziecko pod wpływem lektury przekonuje się, że nie powinno być nieposłuszne, bo próba „nadąsania się na mamę" kończy się płaczem i bólem, samotna wyprawa w pole zostaje przerwana atakiem pszczoły, której użądlenie pozostawia bliznę na twarzy na całe życie (Salusia), róża ma kolce, które boleśnie kłują a konsekwencją gryzienia orzechów, wbrew ostrze-

\footnotetext{
2 Por. T. Boy (2001), Słówka, Gdańsk, Tower Press, np.: O bardzo niegrzecznej literaturze polskiej i jej strapionej ciotce,: s. 9-11, Dwa kotki, s. 226, Deszczyk, s. 227.

3 W nawiasach podaję tytuły utworów.
} 
żeniom ojca, jest brak uzębienia (Andzia, Niepostuszeństwo). Karą dla dziecka jest także cierpienie rodzica wywołane nieposłuszeństwem (Łza matki). Edukacja behawioralna jest skuteczna, gdy zależy nam na wykształceniu w dziecku schematycznych, bezrefleksyjnych zachowań. Skupia się ono na niepopełnianiu błędów i podporządkowaniu woli dorosłego, co zaowocuje brakiem samodzielności. Mimo że żyjemy w XXI w., behawioryzm nadal jest często praktykowany (nawet nieświadomie) przez wielu dydaktyków (Klus-Stańska 2010: 210,217) a szkoła nie rozwija twórczych kompetencji, nie uczy niezależności, samodzielności i przetwarzania informacji (tamże: 33).

Współczesnego odbiorcę razić mogą liczne archaizmy różnego typu: np. podpłomyki, jatmużna, litośna dziecina, napierać się czegoś (Jachowicz 1855a: 35-37, 67-68, 1860: 52, 1860: 3), nieadekwatne do dzisiejszych czasów realia życia: służba w domu, jałmużna dla ubogich oraz wyraźne podziały społeczne (Karolek, Marynia, Gliniana skarbonka 42, Szczesść Boże i Bóg zapłać). Także model rodziny prezentowany w utworach Jachowicza nie koresponduje ze współczesnym. Role męża i żony uległy unifikacji, nie ma dystansu między małżonkami, między rodzicami a dziećmi, kobiety pracują zawodowo (Tyszka 2001). W świecie bajek Jachowicza role w rodzinie są ściśle wyznaczone, choć, co istotne, rozwojem moralnym dziecka zajmują się oboje rodzice. Zarówno ojciec, jak i matka tłumaczą zasady panujące świata, zgodnie uczą obowiązujących norm aktualnych również i dziś: szacunku do człowieka niezależnie od jego statusu społecznego, prawdomówności i pracy. Jednakże matka jest nadwrażliwą, słabą istotą, która płacząc oskarża syna o brak uczuć, gdy chłopiec hałasuje podczas zabawy ( $z$ za matki), tłumi artystyczną swobodę rysującego dziecka, sugerując, by rysowało coś pożytecznego a nie niekształtne postaci (Mały rysownik). Idealny ojciec nie zamyka dziecka w pokoju na klucz, by nauczyć je, zgodnie z popularną w XIX wieku zasadą: „nie rób drugiemu, co tobie niemiłe”, że nie wolno dręczyć żadnych istot żywych (Tadeuszek).

Bajki Jachowicza skierowane są do odbiorcy na poziomie przedkonwencjonalnym i kowencjonalnym rozwoju moralnego, według kryterium przyjętym przez Lawrence'a Kohlberga (Harwas-Napierała, Trempała 2004: 116-115, 2005: 118, 137). Dziecko jest wówczas pod wpływem autorytetu rodzica, zdaje sobie sprawę, że łamanie zasad ustalonych przez dorosłego niesie za sobą zgubne konsekwencje (np. Gdzie wartość prawdziwa, Kwoka i kogucik). Rola rodzica w tym procesie nie pozostawia wątpliwości. Od niego zależy, w jakim stopniu wykształcą się w dziecku takie emocje, jak lęk, poczucie winy, wstyd czy naturalna, wrodzona zdolność empatii (Davis 2001: 36). Umiejętność przyjmowania ról, tzn. przyjmowania spodziewanych przez społeczeństwo postaw, naśladowanie innych, wybieranie swojego „miejsca” w społeczeństwie rośnie wraz z wiekiem (Davis 2001). Jachowicz wykorzystuje tę zależność, odwołując się do emocji małych dzieci, zanim wzmocnią się w nich postawy prospołeczne lub zbuntują się przeciwko nim.

Dziecko na każdym etapie rozwoju pragnie zrozumieć otaczający je świat i prawa nim rządzące, robi to na swój sposób. Utożsamiając się z konkretnym bohaterem bajki, odnajduje rozwiązanie swoich własnych problemów, poznaje samego siebie. Trudno oczekiwać, by w dobie konsumpcjonizmu (Bauman 2006) nawiązało porozumienie ze swoim 
rówieśnikiem sprzed prawie 200 lat. Nie zrozumie potrzeby zaszycia w sukience dziury „póki mała” czy strachu Stasia przed złością mamy za poplamione ubranie (Zaradź złemu zawczasu, Staś). Współczesne społeczeństwo nie gromadzi zapasów, nie oszczędza. Liczy się, to co można mieć teraz - wystarczy karta kredytowa, kredyt zaciągnięty w banku - nie trzeba czekać, by zaspokajać swoje pragnienia.

Świat zmienia się, postępująca technicyzacja życia, globalizacja są nieuchronne. Powrót do świata bajek Jachowicza nie jest możliwy. Warto jednak zatrzymać się „w biegu" i spojrzeć nieco uważniej na to, co proponował Jachowicz swoim podopiecznym. W XXI w. w chaosie informacji, wszechobecnych mediów podających gotowe wzorce życia, akceptowanych bezrefleksyjnie przez odbiorców, przyspieszonego tempa, konsumpcyjnego stylu życia tęsknimy za poczuciem bezpieczeństwa. W świecie bajek Jachowicza wszystko ma swoje miejsce - rodzina, dzieci, przyroda, dobro i zło jest jednoznaczne.

\section{Uwagi końcowe}

Twórczość Stanisława Jachowicza odegrała znaczącą rolę w rozwoju polskiej pedagogiki i może być ważnym źródłem refleksji współczesnego wychowawcy ze względu na jej przesłanie edukacyjne. Wartości zawarte w jego utworach nie straciły na aktualności w XXI wieku i mimo że forma i sposób ich przekazania nie są w stanie trafić do współczesnego młodego odbiorcy, mogą stać się przedmiotem rozmów z czytelnikami - dziećmi i dorosłymi.

Postawienie uczniów przed zadaniem poznania świata oferowanego przez Jachowicza, w sytuacji problemu, jakim jest kontrast pomiędzy dwoma światami - współczesnym i XIX-wiecznym - z wykorzystaniem osobistych doświadczeń, może zaowocować ciekawymi wnioskami. Sam twórca mógłby posłużyć jako przykład współczesnemu pedagogowi - zatroskany o los dzieci ubogich i sierot, skupiony przez całe życie na poprawie ich losu - propagował nowoczesne, jak na tamte czasy, metody wychowawcze.

\section{Literatura}

Bauman Z. (2006), Praca, konsumpcjonizm i nowi ubodzy. Kraków, WAM.

Boy T. (2001), Słówka. Gdańsk, Tower Press. http://www.biblioteka.kijowski.pl/boy-zelenski\%20 tadeusz/slowka.pdf (28.12.2016).

Chrzanowska E. (2006), Stanisław Jachowicz - portret , miłującego bajkopisarza”. „Rocznik Mińsko-Mazowiecki”, t. 14.

Czerpaniak-Walczak M. (1994), Między dostosowaniem a zmianą. Elementy emancypacyjnej teorii edukacji. Szczecin, Uniwersytet Szczeciński.

Cieślikowski J. (1991), Antologia poezji dziecięcej. Wrocław, Ossolineum.

Czechowski J. (2007), Funkcje edukacyjnej literatury dla dzieci i młodzież. „Kultura i Edukacja”, nr 2.

Davis M.H. (2001), Empatia. O umiejętności współodczuwania. Gdańsk, GWP. 
Freire P. (2000), ,Bankowa” koncepcja edukacji jako narzędzie opresji. W: K. Blusz (red.), Edukacja $i$ wyzwolenie. Kraków, Oficyna Wydawnicza Impuls.

Harwas-Napierała B., Trempała J. (red.) (2004), Psychologia rozwoju człowieka. Rozwój funkcji psychicznych. Warszawa, PWN.

Harwas-Napierała B., Trempała J. (red.) (2005), Psychologia rozwoju człowieka. Charakterystyka okresów rozwoju człowieka. Warszawa, PWN.

Jachowicz S., Jachowicz A. (1846-1851), Dzienniki Stanisława i Antoniny Jachowiczów dotyczace rozwoju ich dzieci w pierwszych latach życia. [Dzienniczek Rudzia pisany przez ojca]. T. 1-3, [rękopis], https://polona.pl/item/40768992/8 (10.04.2017).

Jachowicz S. (1860), Bajki i powiastki z ilustracjami Wojciecha Gersona. Petersburg, B.M. Wolff. https://polona.pl/item/10302/4 (28.12.2016).

Jachowicz S. (1824), Bajki i powieści. Płock, K. Kulig https://polona.pl/item/28989/6 (28.12.2016).

Jachowicz S. (1919), Bajki, powiastki, pieśni. Warszawa, M. Arct. https://polona.pl/item/97284/1 (28.12.2016).

Jachowicz S. (1855a), Książeczka dla Stefcia. Warszawa, A. Gins. https://polona.pl/item/43346/3 (21.12.2016).

Jachowicz S. (1862), Podarek dziatkom polskim. Warszawa, Gazeta Polska. https://polona.pl/ item/41927/4 (28.12.2016).

Jachowicz S. (1855b), Rady wuja dla siostrzenic. Warszawa, A. Gins. http://jbc.bj.uj.edu.pl/dlibra/ doccontent?id=283309 (21.12.2016).

Jachowicz S. (1830), Rozmowy mamy z Józią. Warszawa, A. Gałęzowski i Spółka. http://jbc.bj.uj. edu.pl/dlibra/doccontent?id=283293 (21.12.2016).

Jachowicz S. (1869), Śpiewy dzieci. Warszawa, J. Unger. http://jbc.bj.uj.edu.pl/dlibra/docconten$\mathrm{t}$ ?id=206665 (22.12.2016).

Jakubiak K., Nawrot-Borowska M. (2016), Rodzina polska w XIX wieku jako środowisko wychowawcze i jej funkcja edukacyjna. „Studia Paedagogica Ignatiana”, Vol. 19 (2). http://apcz.pl/ czasopisma/index.php/SPI/article/download/SPI.2016.2.001/10361 (22.12.2016).

Jakubiak K. (2014), XIX-wieczne wzorce polskiej rodziny i wychowania rodzinnego dziecka oraz ich oświeceniowe inspiracje. W: Dormus K. i in. (red.), Komisja Edukacji Narodowej. Kontekst historyczno-pedagogiczny. Biblioteka Współczesnej Myśli Pedagogicznej, t. 3, Kraków. http://rep.up.krakow.pl/xmlui/bitstream/handle/11716/247/0051_20150304_gw_ra_19wieczne_wzorce_polskiej_k_jakubiak.pdf?sequence=1 (28.12.2016).

Kaniowska-Lewańska I. (1973), Literatura dla dzieci i młodzieży do roku 1864. Warszawa, WSiP.

Klus-Stańska D. (2010), Dydaktyka wobec chaosu pojęć i znaczeń. Warszawa, Wydawnictwo Akademickie ŻAK.

Kubale A. (1984), Dziecko romantyczne. Wrocław, Ossolineum.

Skimborowicz H. (1858), O Stanisławie Jachowiczu. W: Wieniec, T. 3, Warszawa, A. Gins.

Szymanowski W. (1858), Jachowicz. W: Wieniec, T. 3, Warszawa, A. Gins.

Upominek z prac Stanisława Jachowicza: bajki, nauczki, opisy, powiastki i różne wierszyki (1902), Poznań. https://polona.pl/item/26122/2/ (28.12.2017).

Śliwerski B. (2015), Współczesne teorie i nurty wychowania. Kraków, Oficyna Wydawnicza Impuls. Tyszka Z. (2002), Rodzina we współczesnym świecie. Poznań, Wydawnictwo Naukowe UAM.

Vališová A. (2015), Teachers'authority in relation to their social competence. "Studia Edukacyjne", nr 35 . 
Waksmund R. (2000), Od historii dzieciństwa do etnografii dzieciństwa. W: tegoż, Od literatury dla dzieci do literatury dziecięcej (tematy-gatunki-konteksty). Wrocław, Wydawnictwo Uniwersytetu Wrocławskiego.

Waksmund R. (1986), Literatura pokoju dziecinnego. Warszawa, Nasza Księgarnia.

Wieniec, pismo zbiorowe ofiarowane Stanisławowi Jachowiczowi przez pierwszych kraju autorów oraz licznych jego przyjaciót $i$ wielbicieli. (1858), T. 3, Warszawa, A. Gins. https://books.google. $\mathrm{pl} /$ books? id=9gQEAAAAYAAJ \&pg=PP5\&dq=wstrzymal+slonce + ruszyl+ziemie $\& 1 \mathrm{r}=\&$ as drrb_is $=$ b\&as_minm_is $=0 \&$ as_miny_is $=\& a s \_m a x m \_i s=0 \& a s \_m a x y \_i s=1860 \& a s \_b r r=0 \&$ source $=$ gbs_selected_pages\&redir_esc $=\mathrm{y} \# \mathrm{v}=$ onepage $\& \mathrm{q} \& \mathrm{f}=$ false $(28.12 .2017)$.

Wołoszyn S. (1964), Dzieje wychowania i myśli pedagogicznej w zarysie. Warszawa, PWN. 